\title{
Kondisi mangrove di pesisir timur pulau Jemaja Kepuluan Anambas
}

\author{
Wahyudi Andrito ${ }^{1 *}$, Syafruddin Nasution ${ }^{2}$ Efriyeldi $^{2}$ \\ ${ }^{1}$ Pascasarjana Ilmu Kelautan, Universitas Riau \\ ${ }^{2}$ Fakultas Perikanan dan Ilmu Kelautan, Universitas Riau \\ Koresponden E-mail: wahyudiandrito17@gmail.com
}

(Diterima 18 April 2020|Disetujui 5 Juni 2020|Diterbitkan 30 Juli 2020)

\begin{abstract}
Mangrove ecosystems are one of three important ecosystems in the coastal areas that supports global warming mitigation efforts. The existence of mangrove forests is needed to reduce the increased $\mathrm{CO}_{2}$ concentrations in the atmosphere. However, the rise of the water temperatures and sea levels indirectly affects the presence and condition of mangrove forests in coastal areas. The purpose of this study is to determine the condition of the mangrove community on the East Coast of Jemaja, Anambas Archipelagoes Regency. The survey method was used in this study and a series survey activities were conducted for a quadrant transect with a size of $10 \mathrm{~m}$ by $10 \mathrm{~m}$ in December 2019 - March 2020. The result shown that the five mangrove species were identified, such as Rhizophora apiculata, $R$. mucronata, Bruguiera gymnorrhiza, Ceriops tagal and Xylocarpus granatum. $R$. apiculata dominates with an important value index of $123.12 \%$. While, the average density of mangroves and saplings in the study area was $3155 \pm 785$ individuals/ha and the average canopy cover was $84.03 \pm 3.11 \%$. With this finding, it can be concluded that the condition of mangroves in the East Coast of Jemaja is very dense and still in a good condition.
\end{abstract}

Keywords: importance value index, mangroves, percent cover, density, conservation.

Isu perubahan iklim menjadi topik pembahasan yang sering dibicarakan banyak pakar saat ini. Dunia sedang dikhawatirkan oleh banyak orang karena terjadi ketidakteraturan iklim sehingga banyak organisme hidup yang terdampak. Perubahan iklim atau climate change terjadi karena meningkatnya kosentrasi gas rumah kaca di atmosfer yang dapat mengancam kehidupan manusia dan keanekaragaman hayati. Darmawan et al. (2018) menyatakan bahwa salah satu gas rumah kaca yang banyak terdapat di atmosfer adalah gas $\mathrm{CO}_{2}$. Indonesia sebagai negara kepulauan yang memiliki banyak wilayah pesisir sangat rentan terhadap perubahan iklim. Giri et al. (2011) menyatakan bahwa naiknya suhu perairan dan muka air laut secara tidak langsung berdampak terhadap keberadaan hutan mangrove yang ada di wilayah pesisir. Disisi lain keberadaan hutan mangrove sangat dibutuhkan untuk mereduksi peningkatan konsentrasi gas $\mathrm{CO}_{2}$ di atmosfer. Parera et al. (2019) menyatakan bahwa mangrove dapat menyerap sebagian besar $\mathrm{CO}_{2}$ dari atmosfer pada saat proses fotosintesis serta menyimpannya dalam struktur jaringan batang dan sedimen dalam jangka waktu yang lama.

Tekanan terhadap ekosistem mangrove di Indonesia terus terjadi hingga saat ini. Hal ini menyebabkan semakin menurunnya kualitas dan kuantitas ekosistem mangrove. Pramono (2018) menyebutkan bahwa sampai tahun 2015 luasan mangrove Indonesia adalah 3.489.140 ha, dimana 1,82 juta ha dalam kondisi rusak dan 1,67 juta ha dalam kondisi baik.

Pembentukan kawasan konservasi merupakan salah satu upaya yang dapat dilakukan untuk melindungi keberadaan ekosistem mangrove. Melalui Kementerian Kelautan dan Perikanan, pemerintah menetapkan salah satu Kawasan Konservasi Perairan
Nasional (KKPN) di Kabupaten Kepulauan Anambas berdasarkan Keputusan Menteri Kelautan dan Perikanan Nomor 37/KEPMEN-KP/2014 tentang Penetapan KKPN Taman Wisata Perairan (TWP) Kepulauan Anambas dan Laut Sekitarnya. Luas kawasan konservasi ini seluruhnya adalah 1.262.686,2 ha yang meliputi Kecamatan Palmatak, Siantan Tengah, Siantan Timur, Siantan Selatan, Jemaja dan Jemaja Timur. Ekosistem mangrove merupakan salah satu dari tiga ekosistem laut tropis yang ada di TWP Kepulauan Anambas dan menjadi target pengelolaan kawasan konservasi ini.

Pesisir Timur Jemaja merupakan bagian dari kawasan konservasi TWP Kepulauan Anambas yang masuk ke dalam Kecamatan Jemaja Timur. Daerah ini memiliki banyak teluk dan pantai yang terlindung sehingga menjadi salah satu habitat hutan mangrove yang banyak dijumpai dibandingkan di pesisir bagian utara maupun bagian selatan Pulau Jemaja. Selain itu, pendataan ekosistem mangrove yang dilakukan oleh pengelola kawasan TWP Kepulauan Anambas selama ini masih terkonsentrasi pada Kecamatan Palmatak, Siantan Selatan dan Siantan Tengah sehingga data yang ada belum lengkap.

Aktifitas pembukaan lahan untuk pembuatan jalan, perluasan pemukiman penduduk, pembuatan lapangan olah raga dan pembanguan dermaga oleh pemerintah setempat, serta banyaknya buangan sampah plastik ke laut menjadi ancaman bagi komunitas mangrove yang ada di Kecamatan Jemaja Timur. Selain itu, di bagian Utara Kabupaten Kepulauan Anambas banyak terdapat Wilayah Kerja Pertambangan (WKP) Minyak dan Gas yang berpotensi terjadinya kebocoran minyak sehingga dapat menyebabkan kerusakan pada habitat mangrove yang ada di Pesisir Timur Jemaja. Untuk mengetahui kondisi mangrove di Pesisir Timur Jemaja perlu untuk 
dilakukan penelitian ini yang dapat dijadikan sebagai data dasar dan data dukung bagi pengelola kawasan konservasi TWP Kepulauan Anambas di masa yang akan datang.

\section{BAHAN DAN METODE}

Penelitian ini dilaksanakan pada bulan Desember 2019 sampai Maret 2020 dengan lokasi pengambilan data pada kawasan mangrove di Pesisir
Timur Jemaja Kabupaten Kepulauan Anambas (Gambar 1). Metode yang digunakan dalam penelitian ini adalah metode survei, penentuan titik stasiun penelitian menggunakan purposive sampling dengan mempertimbangkan keterwakilan mangrove tiap zona dalam kawasan konservasi, keterwakilan ketebalan komunitas mangrove dan keterwakilan jarak dari lokasi pemukiman.

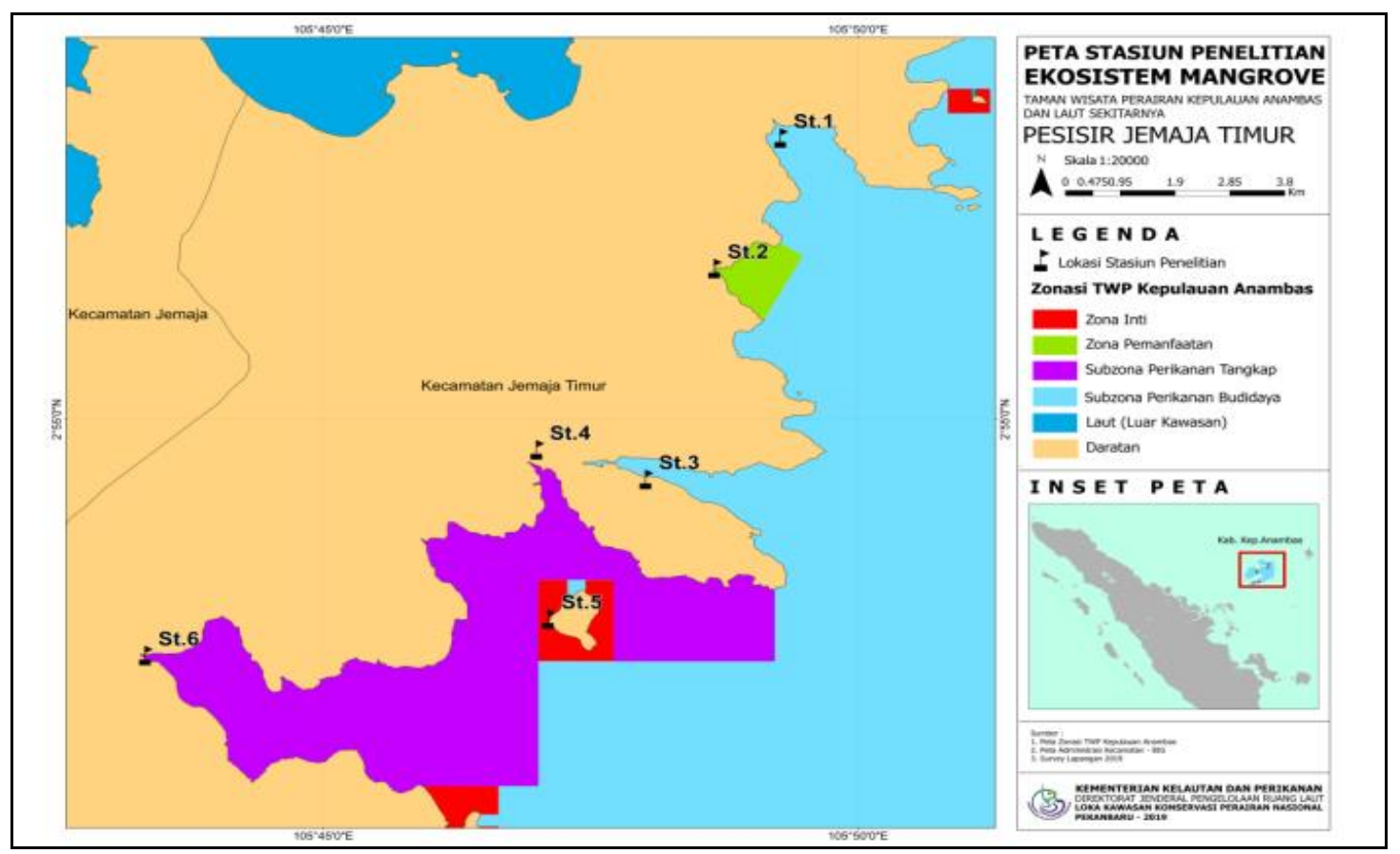

Gambar 1. Peta Pesisir Timur Pulau Jemaja dan Titik Stasiun Pengamatan

Pengambilan data vegetasi dilakukan menggunakan metode transek petakan kuadran atau petakan contoh (transect plot) ukuran 10x10 m. Jumlah stasiun pengamatan ditentukan sebanyak 6 stasiun, tiap stasiun pengamatan dibuat transek sepanjang $\pm 100 \mathrm{~m}$ (disesuaikan dengan kondisi di lapangan). Tiap transek dibuat plot $10 \times 10 \mathrm{~m}$ dengan 3 kali pengulangan. Ketentuan pembuatan transek dan peletakan plot pengamatan pada setiap stasiun mengacu pada Darmawan \& Pramudji (2017).

Data yang diambil pada penelitian ini meliputi jumlah spesies tegakan mangrove, diameter batang, tinggi pohon, dan persen penutupan tajuk. Disamping itu juga diambil data jumlah tebangan, jumlah sampah plastik dan tipe sedimen. Parameter kualitas perairan diukur dengan menggunakan alat DKK - TOA WQC24 secara langsung di lapangan untuk mendapatkan data $\mathrm{pH}, \mathrm{DO}$, salinitas, temperatur dan kekeruhan.

Vegetasi mangrove yang diamati adalah strata pohon, pancang dan semai. Pada penelitian ini yang dimaksud dengan pohon adalah semua tumbuhan berkayu dengan diameter batang setinggi dada (pada ketinggian $130 \mathrm{~cm}$ di atas permukaan tanah) $\geq 4 \mathrm{~cm}$ atau diameter batang 12,56 cm (English et al., 1994). Pancang adalah permudaan yang tingginya mencapai
$100 \mathrm{~cm}$ dengan diameter batang kurang dari $4 \mathrm{~cm}$, sedangkan semai merupakan permudaan yang tumbuh mulai dari kecambah sampai pancang dengan ketinggian kurang dari $100 \mathrm{~cm}$ (Bengen, 2004).

Setiap tumbuhan berkayu yang dijumpai dalam plot pengamatan di ukur diameter batangnya dan kemudian di identifikasi sampai pada tingkat spesies dengan mengacu pada buku panduan identifikasi vegetasi mangrove (Giesen et al., 2006). Sedangkan semai dihitung jumlah individu tiap jenis dalam plot pengamatan tanpa mengukur diameter batangnya.

Posisi pengukuran diameter batang strata pohon dan pancang mangrove pada beberapa tipe batang yang dipengaruhi oleh sistem perakaran dan percabangan mengacu pada Keputusan Menteri Lingkungan Hidup RI No. 201 tahun 2004 tentang Kriteria Baku dan Pedoman Penentuan Kerusakan Mangrove.

\section{Indeks Nilai Penting (INP)}

Nilai INP merupakan indeks kepentingan yang menggambarkan pentingnya peranan suatu jenis vegetasi dalam ekosistemnya. Nilai INP diperoleh dari penjumlahan nilai kerapatan relatif jenis $\left(K R_{i}\right)$, frekuensi relatif jenis $\left(F R_{i}\right)$ dan Dominansi relatif jenis $\left(D R_{i}\right)$. Nilai kerapatan, frekuensi dan dominansi 
vegetasi dihitung menurut (English et al., 1994). Kerapatan, kerapatan relatif, frekuensi, frekuensi relatif, dominasi, dominansi relatif dan INP dapat ditentukan dengan rumus secara berurutan sebagai berikut :

Kerapatan Jenis $\left(K_{i}\right)$

$K_{i}=\frac{n_{i}}{A}$

dimana,

$K_{i}$ ialah kerapatan jenis ke- $i$,

$n_{i}$ merupakan umlah total tegakan jenis ke-i, dan

$A$ adalah luas area total pengambilan contoh.

Kerapatan Relatif Jenis $\left(K R_{i}\right)$

$K R_{i}=\left[\frac{n_{i}}{\Sigma N}\right] x 100 \%$

dimana,

$K R_{i}$ merupakan kerapatan relatif jenis ke-i,

$n_{i}$ adalah jumlah total tegakan jenis ke-i, dan

$\sum N$ merupakan jumlah total tegakan seluruh jenis.

Frekuensi Jenis $\left(F_{i}\right)$

$F_{i}=\frac{p_{i}}{\sum p}$

dimana,

$F_{i}$ adalah frekuensi jenis ke- $i$

$p_{i}$ merupakan jumlah plot ditemukan jenis ke- $i$, dan

$\sum P$ adalah jumlah total plot pengamatan.

Frekuensi Relatif Jenis $\left(F R_{i}\right)$

$F R_{i}=\left[\frac{F_{i}}{\sum F}\right] x 100 \%$.

dimana,

$F R_{i}$ merupakan frekuensi relatif jenis ke-i,

$F_{i}$ adalah jumlah frekuensi jenis ke- $i$, dan

$\sum F$ merupakan jumlah total frekuensi seluruh jenis.

Dominansi Jenis $\left(D_{i}\right)$

$D_{i}=\frac{B A_{i}}{\sum A}$

dimana,

$D_{i}$ ialah dominansi jenis ke- $i$,

$B A_{i}$ adalah basal Area jenis ke- $i$ - sedangkan

$B A=\frac{\pi D^{2}}{4}$, yang mana $\pi=3,14$

$D$ merupakan diameter, dan

$\sum A$ adalah luas area total pengambilan contoh.
$D R_{i}=\frac{D_{i}}{\sum D} x 100 \%$

dimana,

$D R_{i}$ adalah dominansi relatif jenis ke- $i$,

$D_{i}$ merupakan jumlah dominansi jenis ke-i, dan

$\sum D$ adalah jumlah total dominansi seluruh jenis.

\section{Indek Nilai Penting (INP)}

INP adalah jumlah nilai kerapatan relatif jenis $\left(K R_{i}\right)$, frekuensi relatif jenis $\left(F R_{i}\right)$, dan Dominansi relatif jenis $\left(D R_{i}\right)$.

$I N P=K R_{i}+F R_{i}+D R_{i}$

yang mana,

$I N P$ adalah indeks nilai penting,

$K R_{i}$ adalah kerapatan relatif jenis ke- $i$,

$F R_{i}$ adalah frekuensi relatif jenis ke- $i$, dan

$D R_{i}$ adalah dominansi relatif jenis ke- $i$.

\section{Tinggi Pohon}

Data tinggi tegakan pohon mangrove diperoleh dari data ketinggian mata pengamat dari tanah dan hasil pengukuran jarak pengamat ke pohon serta sudut kemiringan antara mata pengamat dengan puncak pohon. Pengukuran tinggi tegakan pohon mangrove dilakukan pada masing-masing plot ukuran 10x10 m. Pohon yang diukur ketinggiannya adalah pohon tertinggi dan beberapa pohon yang memiliki ketinggian rata-rata.

Untuk mendapatkan nilai sudut kemiringan antara mata pengamat dengan puncak pohon menggunakan alat komunikasi berupa handphone yang memilki aplikasi protractor. Untuk menghitung tinggi tegakan $(H)$ dapat menggunakan rumus sebagai berikut

$H=h_{0}+h_{1}$

dimana,

$h_{0}$ adalah tinggi mata pengamat, dan

$h_{1}$ merupakan jarak $x \tan \theta$.

\section{Persen tutupan tajuk}

Persentase tutupan tajuk mangrove dihitung dengan menggunakan metode hemispherical photography yaitu teknik untuk memperkirakan radiasi matahari dan mengkarakterisasi geometri tajuk tanaman menggunakan foto yang diambil dengan melihat ke atas melalui lensa kamera. Teknik ini cenderung cukup baru digunakan pada hutan mangrove di Indonesia, penerapannya mudah dan menghasilkan data yang lebih akurat (Dharmawan \& Pramudji, 2017).

Dominansi Relatif Jenis $\left(D R_{i}\right)$ 


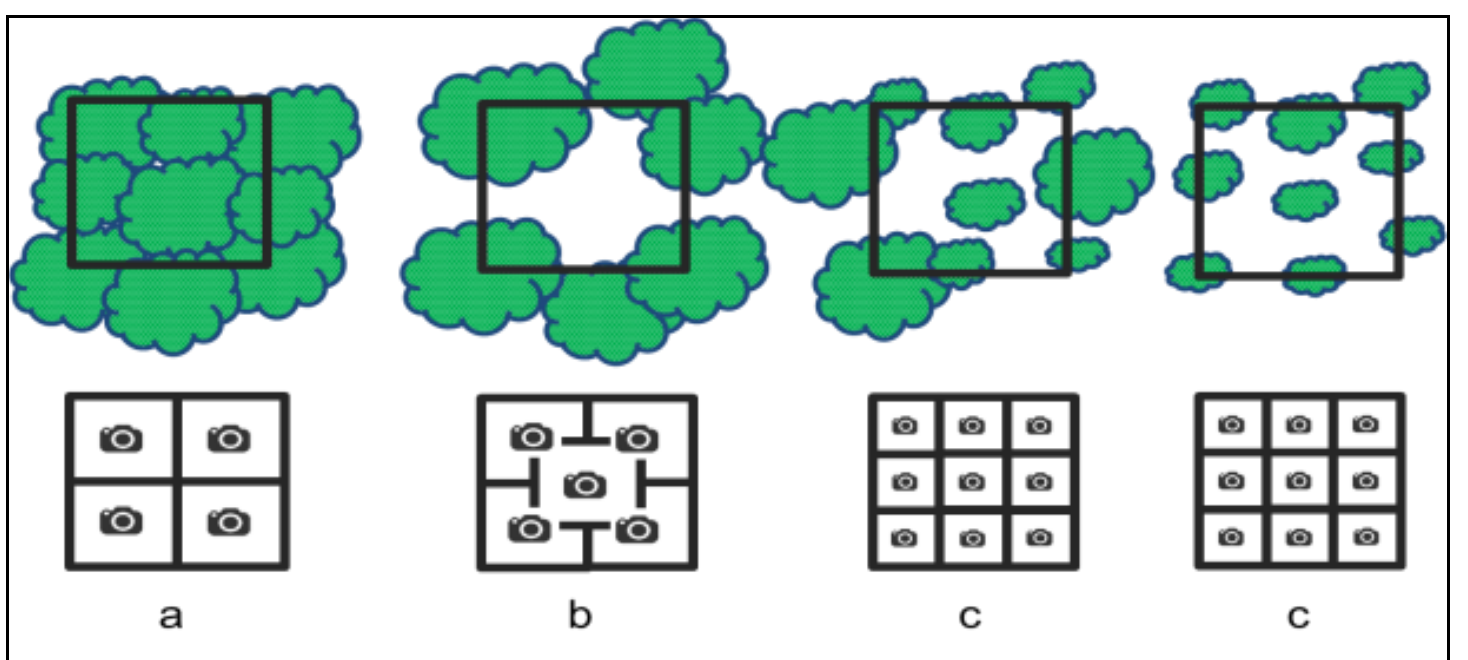

Gambar 2.Ilustrasi jumlah dan posisi pengambilan foto hemisphere dalam plot 10x10 m pada masing-masing kondisi tajuk. (a) kondisi tajuk padat, (b) kondisi tajuk terbuka bagian tengah, dan (c) kondisi tajuk tidak beraturan.

Foto hemispherical dianalisis dengan menggunakan software image $J$ untuk memisahkan pixel tutupan vegetasi mangrove dan pixel langit. Selanjutnya, dihitung nilai pixel tutupan vegetasi mangrove dan nilai pixel keseluruhan dalam satu foto hemispherical. Nilai tutupan mangrove diperoleh dari hasil perbandingan jumlah pixel tutupan mangrove P255 dengan jumlah seluruh pixel $(\Sigma P)$, dengan demikian persentase tutupan mangrove dapat dihitung menggunakan rumus sebagai berikut:

$\%$ Tutupan $=\frac{\sum P 255}{\sum P} \times 100 \%$

dimana,

$\sum$ P255 ialah jumlah pixel tutupan, dan

$\sum P$ adalah jumlah total pixel.

\section{Jumlah Tebangan}

Jumlah tebangan pohon mangrove dalam setiap plot 10x10 m dicatat dan dihitung untuk dijadikan sebagai data dukung penelitian yang menggambarkan kondisi kerusakan fisik mangrove di lokasi penelitian.

\section{Jumlah Sampah Plastik}

Sampah plastik merupakan salah satu sampah anorganik yang memerlukan waktu lama untuk terurai secara sempurna di alam. Lamanya waktu penguraian sampah plastik ini akan berdampak pada regenerasi mangrove di lingkungan tersebut. Hal ini dikarenakan dapat menghalangi propagul untuk menempel pada substrat saat air laut surut. Selain itu sampah plastik yang menempel pada akar mangrove akan menurunkan luasan permukaan respirasi dan permukaan pengambilan unsur hara dan pada akhirnya mengganggu pertumbuhan pohon mangrove.

Sampah plastik dikelompokkan menjadi tiga ukuran berdasarkan Darmawan \& Pramudji (2017). Ukuran kecil jika sampah plastik yang ditemukan dalam plot pengamatan kurang dari $100 \mathrm{~cm}^{2}$, ukuran sedang jika sampah plastik yang ditemukan dalam plot pengamatan berukuran $100-1600 \mathrm{~cm}^{2}$, ukuran besar jika sampah plastik yang ditemukan dalam plot pengamatan berukuran $>1600 \mathrm{~cm}^{2}$. Jumlah sampah plastik dihitung pada setiap plot ukuran 10x10 m untuk mendapatkan gambaran kondisi kerusakan dan potensi terjadinya pencemaran sampah plastik per satuan luas.

\section{HASIL}

Pesisir Timur Jemaja merupakan bagian dari wilayah administrasi Kecamatan Jemaja Timur Kabupaten Kepulauan Anambas. Secara geografis kecamatan ini terletak pada $02^{0} 48^{\prime} 51^{\prime \prime}$ - $03^{\circ} 00^{\prime} 58^{\prime \prime}$ Lintang Utara dan $105^{\circ} 41^{\prime} 27^{\prime \prime}$ - 105 51' 17" Bujur Timur. Bagian utara dan selatan kecamatan ini berbatasan dengan Laut Natuna Utara, bagian barat berbatasan dengan Kecamatan Jemaja dan bagian timur berbatasan dengan Kecamatan Siantan Selatan.

Mangrove di Pesisir Timur Jemaja Kabupaten Kepulauan Anambas merupakan mangrove alami yang tumbuh baik di daerah yang memiliki aliran sungai dengan substrat berlumpur. Berdasarkan hasil pengamatan yang dilakukan terhadap vegetasi mangrove di enam stasiun pengamatan, ditemukan 5 jenis mangrove. Kelima jenis tersebut adalah dari jenis Rhizophora apiculata, $R$. mucronata, Bruguiera gymnorrhiza, Ceriops tagal dan Xylocarpus granatum.

Tabel 1. Kehadiran jenis mangrove tiap stasiun pengamatan

\begin{tabular}{|c|c|c|c|c|c|c|}
\hline \multirow{2}{*}{\multicolumn{2}{|c|}{$\begin{array}{c}\text { Stasiun } \\
\text { Pengamatan }\end{array}$}} & \multicolumn{5}{|c|}{ Jenis Mangrove*) } \\
\hline & & $\mathbf{R a}$ & $\mathbf{R m}$ & Bg & $\mathrm{Ct}$ & $\mathrm{Xg}$ \\
\hline & St.1 & + & + & + & + & + \\
\hline & St. 2 & + & - & + & - & + \\
\hline & St. 3 & + & - & + & - & - \\
\hline & St.4 & + & - & + & + & + \\
\hline & St. 5 & + & + & + & - & + \\
\hline & St. 6 & + & + & + & - & - \\
\hline *) & \multicolumn{6}{|c|}{$\begin{array}{l}: \text { Ra }=R . \text { apiculata } ; \mathrm{Rm}=R . \text { mucronata } ; \mathrm{Bg}=B . \\
\text { gymnorrhiza; } X . \text { granatum dan } \mathrm{Ct}=C . \text { tagal }\end{array}$} \\
\hline+ & \multicolumn{6}{|c|}{ : Ditemukan } \\
\hline - & \multicolumn{6}{|c|}{ : Tidak ditemukan } \\
\hline
\end{tabular}


Dari Tabel 1 di atas diketahui bahwa jenis mangrove yang ditemukan tiap stasiun pengamatan (St.1-6) memiliki komposisi yang berbeda. Jenis mangrove $R$. apiculata dan $B$. gymnorrhiza ditemukan pada tiap stasiun pengamatan. Sedangkan pada stasiun pengamatan St. 3 hanya ditemukan dua jenis mangrove yaitu dari jenis $R$. apiculata dan B. gymnorrhiza.

Nilai rata-rata kerapatan tertinggi kelas pohon, pancang dan semai secara berurutan berada pada stasiun pengamatan St.3 (2133 \pm 764 ind/ha), St.4 $(2333 \pm 2203 \mathrm{ind} / \mathrm{ha})$ dan St.1 (4167 $\pm 1804 \mathrm{ind} / \mathrm{ha})$. Sedangkan nilai rata-rata kerapatan terendah kelas pohon, pancang dan semai secara berurutan berada pada stasiun pengamatan St.1 (1167 \pm 306 ind $/ \mathrm{ha})$, St.2 (967 $\pm 58 \mathrm{ind} / \mathrm{ha})$ dan St.2 (1333 $\pm 115 \mathrm{ind} / \mathrm{ha})$.

Dari hasil analisis ANOVA tidak ditemukan perbedaan nilai kerapatan yang signifikan antar stasiun pengamatan baik pada kelas pohon $(P=0,407)$, pancang $(P=0,629)$ dan semai $(P=0,283)$. Kondisi kerapatan ratarata mangrove di Pesisir Timur Jemaja termasuk dalam kategori sangat padat berdasarkan Keputusan Menteri Lingkungan Hidup nomor 201 Tahun 2004 dengan rentang kerapatan di atas 1500 ind/ha.

Tabel 2. Nilai rata-rata ( \pm Standar deviasi) kerapatan; jumlah jenis; INP; tutupan; tinggi pohon; jumlah tebangan, dan jumlah sampah plastik tiap stasiun pengamatan

\begin{tabular}{|c|c|c|c|c|c|c|c|c|}
\hline \multirow{2}{*}{ No } & \multirow{2}{*}{ Parameter } & \multicolumn{6}{|c|}{ Stasiun Pengamatan } & \multirow{2}{*}{ TOT } \\
\hline & & 1 & 2 & 3 & 4 & 5 & 6 & \\
\hline \multirow[t]{4}{*}{1} & \multicolumn{8}{|l|}{ Kerapatan (Ind/ ha) } \\
\hline & Kelas Pohon & $1167 \pm 306$ & $\begin{array}{c}1367 \pm \\
231\end{array}$ & $\begin{array}{c}2133 \pm \\
764\end{array}$ & $\begin{array}{c}1633 \pm \\
802\end{array}$ & $\begin{array}{c}2033 \pm \\
493\end{array}$ & $\begin{array}{c}1333 \pm \\
971\end{array}$ & $\begin{array}{c}1611 \pm \\
297\end{array}$ \\
\hline & Kelas Pancang & $1100 \pm 173$ & $967 \pm 58$ & $\begin{array}{c}2000 \pm \\
1744\end{array}$ & $\begin{array}{c}2333 \pm \\
2203\end{array}$ & $1067 \pm 58^{\mathrm{a}}$ & $\begin{array}{c}1800 \pm \\
700\end{array}$ & $\begin{array}{l}1544 \pm \\
934\end{array}$ \\
\hline & Kelas Semai & $\begin{array}{c}4167 \pm \\
1804\end{array}$ & $\begin{array}{c}1333 \pm \\
115\end{array}$ & $\begin{array}{c}3167 \pm \\
2511\end{array}$ & $\begin{array}{c}3600 \pm \\
2179\end{array}$ & $\begin{array}{c}1833 \pm \\
702\end{array}$ & $\begin{array}{c}2333 \pm \\
1234\end{array}$ & $\begin{array}{c}2739 \pm \\
913\end{array}$ \\
\hline 2 & Jumlah Jenis & 5 & 4 & 2 & 4 & 4 & 3 & $\begin{array}{c}3,67 \pm \\
1,03\end{array}$ \\
\hline \multirow[t]{3}{*}{3} & \multicolumn{8}{|c|}{ Indeks Nilai Penting $\left.(\mathrm{INP})^{*}\right)$ Kelas Pohon dan Pancang } \\
\hline & Tertinggi & $\mathrm{Bg}: 120,47$ & $\begin{array}{l}\mathrm{Ra}: \\
132,21\end{array}$ & $\begin{array}{c}\mathrm{Ra}: \\
203.60\end{array}$ & $\begin{array}{c}\mathrm{Xg}: \\
136,71\end{array}$ & $\begin{array}{c}\mathrm{Ra}: \\
131.65\end{array}$ & $\begin{array}{l}\mathrm{Bg}: \\
162,79\end{array}$ & $\begin{array}{c}\mathrm{Ra}: \\
123,12\end{array}$ \\
\hline & Terendah & $\mathrm{Xg}: 19,78$ & $\begin{array}{l}\mathrm{Rm}: \\
19,66\end{array}$ & $\begin{array}{l}\mathrm{Bg}: \\
96,40\end{array}$ & $\mathrm{Ct}: 15,26$ & $\mathrm{Xg}: 11,10$ & $\begin{array}{l}\mathrm{Rm}: \\
42,00\end{array}$ & $\mathrm{Ct}: 13,24$ \\
\hline 4 & Tutupan $(\%)$ & $\begin{array}{c}78,24 \pm \\
4,33\end{array}$ & $\begin{array}{c}86,06 \pm \\
0,92\end{array}$ & $\begin{array}{c}87,81 \pm \\
1,60\end{array}$ & $\begin{array}{c}76,11 \pm \\
8,81^{\mathrm{f}}\end{array}$ & $\begin{array}{c}85,96 \pm \\
0,37\end{array}$ & $\begin{array}{c}90,00 \pm \\
3,27^{\mathrm{d}}\end{array}$ & $\begin{array}{l}84,03 \pm \\
3,11\end{array}$ \\
\hline 5 & Tinggi (m) & $4,1 \pm 0,4^{\mathrm{bc}}$ & $\begin{array}{l}6,8 \pm \\
0,7^{\text {acdef }}\end{array}$ & $\begin{array}{l}2,7 \pm \\
0,4^{\text {abef }}\end{array}$ & $3,7 \pm 0,7^{\mathrm{b}}$ & $\begin{array}{l}4,79 \pm \\
0,27^{\mathrm{bc}}\end{array}$ & $\begin{array}{l}4,8 \pm \\
0,3^{\mathrm{bc}}\end{array}$ & $\begin{array}{c}4,79 \pm \\
0,27\end{array}$ \\
\hline 6 & $\begin{array}{l}\text { Diameter Batang } \\
(\mathrm{cm})\end{array}$ & $8,20 \pm 1,80$ & $\begin{array}{c}11,93 \pm \\
1,61^{\mathrm{cd}}\end{array}$ & $\begin{array}{c}6,04 \pm \\
0,88^{\mathrm{b}}\end{array}$ & $\begin{array}{c}7,57 \pm \\
1,69^{\mathrm{b}}\end{array}$ & $\begin{array}{c}9,21 \pm \\
0,50\end{array}$ & $\begin{array}{c}8,93 \pm \\
2,06\end{array}$ & $\begin{array}{c}8,64 \pm \\
0,60\end{array}$ \\
\hline $\begin{array}{l}7 \\
8\end{array}$ & $\begin{array}{l}\text { Jumlah Tebangan } \\
\text { (pohon/ha) } \\
\text { Jumlah Sampah Pl }\end{array}$ & $\begin{array}{l}533 \pm 208 \\
\text { stik (unit/ ha) }\end{array}$ & $33 \pm 58$ & $\begin{array}{c}133 \pm \\
231\end{array}$ & $667 \pm 58$ & - & - & $228 \pm 102$ \\
\hline & Kecil $<100 \mathrm{~cm}^{2}$ & - & - & 200 & - & 300 & - & \\
\hline & $\begin{array}{l}\text { Sedang } 100- \\
1600 \mathrm{~cm}^{2}\end{array}$ & - & - & 1600 & 300 & 1100 & - & \\
\hline & Besar $>1600 \mathrm{~cm}^{2}$ & - & - & 500 & - & 200 & - & \\
\hline
\end{tabular}

Indeks Nilai Penting (INP) pada setiap spesies dapat menggambarkan dominasi suatu spesies disetiap stasiun pengamatan. Secara keseluruhan, komunitas mangrove di Pesisir Timur Jemaja Kabupaten Kepulauan Anambas didominasi oleh jenis $R$. apiculata yang ditunjukkan oleh nilai INP rata-rata tertinggi, yaitu $123,12 \%$.

Tingginya INP dari jenis R. apiculata karena di setiap stasiun pengamatan (St.1-6) dijumpai jenis ini dan memiliki jumlah pohon yang lebih banyak dari pada jenis $B$. gymnorrhiza yang juga ditemukan di setiap stasiun pengamatan (Gambar 3). Hal ini didukung oleh faktor lingkungan yang baik sehingga jenis ini dapat tumbah dan berkembang dengan baik pula. Sedangkan nilai INP rata-rata terendah adalah dari jenis $C$. tagal dengan nilai INP yaitu $13,24 \%$.

Kondisi tutupan komunitas mangrove disetiap stasiun pengamatan termasuk dalam kategori baik berdasarkan Keputusan Menteri Lingkungan Hidup nomor 201 Tahun 2004 dengan rentang persentase tutupan tajuk, yaitu: 76,11 $\pm 8,81 \%$ (St.4) sampai 90,00 $\pm 3,27 \%$ (St.6). Berdasarkan nilai signifikansi ANOVA 
$(\mathrm{P}=0,017)$, ini menunjukkan bahwa nilai rata-rata tutupan tajuk antar stasiun pengamatan berbeda nyata. Stasiun pengamatan yang memiliki nilai perbedaan yang nyata berdasarkan uji lanjut Tukey adalah stasiun pengamatan St.4 dan St.6 dengan nilai signifikasi sebesar $\mathrm{P}=0,030$.

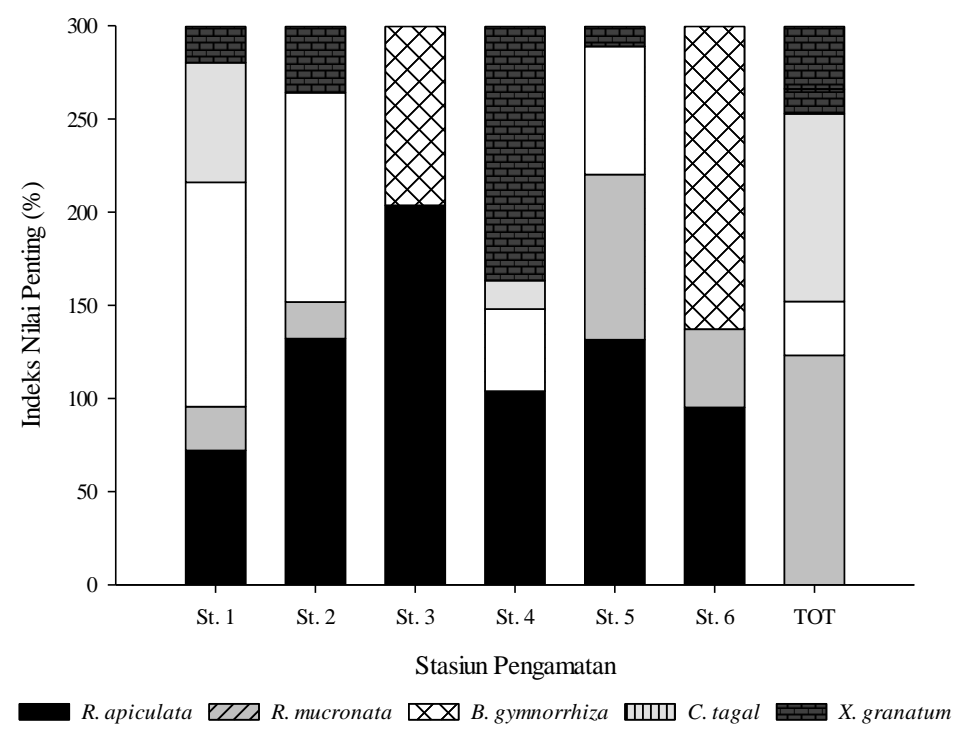

Gambar 3. Indeks Nilai Penting dari masing-masing jenis mangrove yang ditemukan disetiap stasiun pengamatan (St.1-6) dan nilai rata-rata total (TOT)

Diameter rata-rata batang mangrove pada kelas pohon dan pancang di Pesisir Timur Jemaja Kabupaten Kepulauan Anambas sebesar 8,64 \pm 0,60 $\mathrm{cm}$. Diameter rata-rata diameter batang pada kelas pohon dan pancang tertinggi berada pada stasiun pengamatan St.2 (11,93 $\pm 1,61 \mathrm{~cm})$ sedangakan diameter rata-rata diameter batang terendah berada pada stasiun pengamatan St.3 $(6,04 \pm 0,88 \mathrm{~cm})$. Spesies B. gymnorrhiza memiliki diameter batang paling besar pada lokasi penelitian yaitu sebesar $75,73 \mathrm{~cm}$.

Nilai signifikansi ANOVA diameter diameter batang adalah $\mathrm{P}=0,007$ yang menunjukkan terdapat nilai diameter batang yang berbeda nyata antar stasiun pengamatan. Berdasarkan uji lanjut Tukey, nilai ratarata diameter batang stasiun pengamatan St. 2 berbeda nyata dengan nilai rata-rata diameter batang stasiun pengamatan St.3 $(\mathrm{P}=0,004)$ dan St.4 $(\mathrm{P}=0,024)$, nilai rata-rata diameter batang stasiun pengamatan St.3 berbeda nyata dengan nilai rata-rata diameter batang stasiun pengamatan St. $2(\mathrm{P}=0,004)$ dan nilai rata-rata diameter batang stasiun pengamatan St.4 berbeda nyata dengan nilai rata-rata diameter batang stasiun pengamatan St.2 $(\mathrm{P}=0,024)$.

Nilai rata-rata diameter batang berbanding lurus dengan nilai rata-rata tinggi pohon mangrove yaitu $4,47 \pm 0,20 \mathrm{~m}$. Nilai rata-rata tinggi pohon tertinggi berada pada stasiun pengamatan St.2 dengan nilai 6,8 $\pm 0,7 \mathrm{~m}$ sedangkan nilai rata-rata tinggi pohon terendah berada pada stasiun pengamatan St.3 dengan nilai 2,7 \pm 0,4 $\mathrm{m}$ (Gambar 4).

Nilai signifikansi ANOVA rata-rata tinggi pohon adalah $\mathrm{P}=0,000$ yang menunjukkan terdapat nilai rata-rata tinggi pohon yang berbeda nyata dengan stasiun pengamatan lainnya. Berdasarkan uji lanjut Tukey, nilai rata-rata tinggi pohon stasiun pengamatan St. 1 berbeda nyata dengan nilai rata-rata tinggi pohon stasiun pengamatan St.2 $(\mathrm{P}=0,000)$ dan St.3 $(\mathrm{P}=0,41)$, nilai rata-rata tinggi pohon stasiun pengamatan St. 2 berbeda nyata dengan nilai rata-rata tinggi pohon stasiun pengamatan St.1 $(\mathrm{P}=0,000)$, St. 3 $(P=0,000)$, St.4 $(P=0,000)$, St.5 $(P=0,003)$ dan St.6 $(\mathrm{P}=0,003)$, nilai rata-rata stasiun pengamatan St. 3 berbeda nyata dengan nilai rata-rata tinggi pohon stasiun pengamatan St.1 $(\mathrm{P}=0,041)$, St. $2(\mathrm{P}=0,000)$, St.5 $(\mathrm{P}=0,002)$ dan St.6 $(\mathrm{P}=0,003)$, nilai rata-rata stasiun pengamatan St.4 berbeda nyata dengan nilai rata-rata tinggi pohon stasiun pengamatan St.2 $(\mathrm{P}=0,000)$, nilai rata-rata stasiun pengamatan St.5 berbeda nyata dengan nilai rata-rata tinggi pohon stasiun pengamatan St.2 $(\mathrm{P}=0,003)$ dan St. $3(\mathrm{P}=0,002)$, nilai rata-rata stasiun pengamatan St. 6 berbeda nyata dengan nilai rata-rata tinggi pohon stasiun pengamatan St. $2(\mathrm{P}=0,003)$ dan St. $3(\mathrm{P}=0,003)$. 


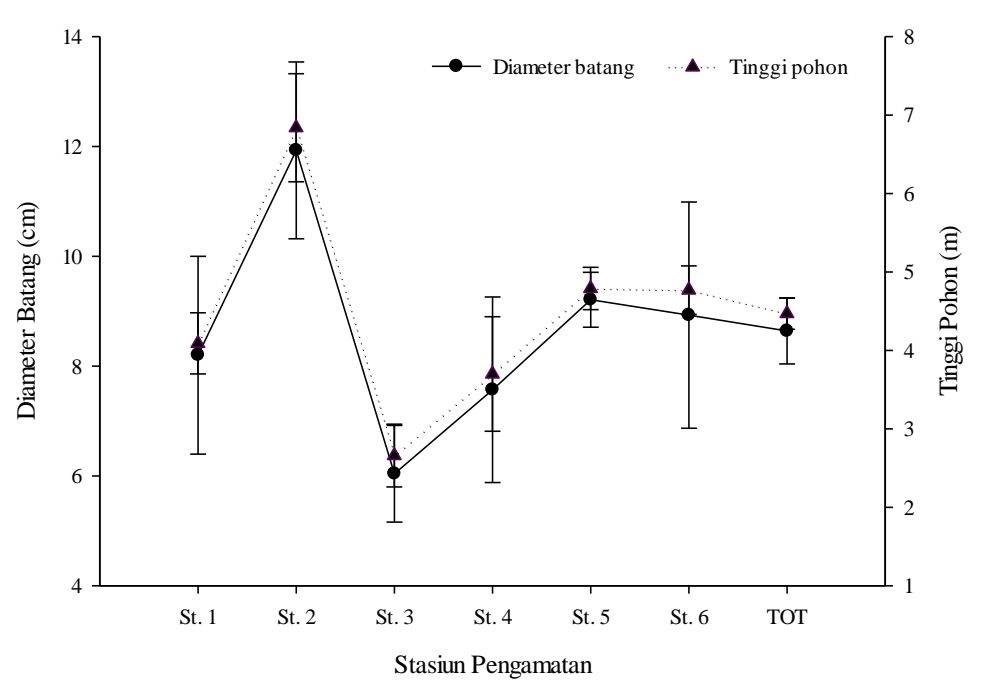

Gambar 4. Perbandingan diameter rata-rata batang kelas pohon dan pancang serta tinggi pohon di setiap stasiun pengamatan (St.1-6) dan nilai rata-rata total (TOT)

Ancaman kerusakan pada komunitas mangrove dapat dilihat seberapa banyak tebangan dan sampah plastik yang ada lokasi tersebut. Penebangan batang pohon mangrove secara berlebihan dapat mengakibatkan terjadinya penurunan fungsi hutan mangrove begitu juga dengan sampah plastik akan dapat menyebabkan terjadinya pencemaran dan menghalangi propagul untuk menempel pada substratnya.

Ekosistem mangrove di Pesisir Timur Jemaja Kabupaten Kepulauan Anambas merupakan bagian dari kawasan konservasi Taman Wisata Perairan (TWP) Kepulauan Anambas yang terjaga dari aksi perambahan dan penebangan pohon mangrove. Akan tetapi upaya pengelolaan kawasan konservasi ini belum sepenuhnya optimal karena dari hasil penelitian yang dilakukan di daerah tersebut masih ditemukan beberapa pohon mangrove yang ditebang. Dari 6 stasiun pengamatan terdapat 4 stasiun pengamatan yang terdapat bekas tebangan yaitu stasiun pengamatan St.1, St.2, St, 3 dan St.4. Hanya pada stasiun pengamatan St.5 dan St. 6 yang tidak ditemukan bekas tebangan.

Rata-rata tebangan pohon mangrove di Pesisir Timur Jemaja Kabupaten Kepulauan Anambas sebesar $228 \pm 102$ pohon/ha. Stasiun pengamatan St. 4 merupakan lokasi yang paling banyak ditemukan bekas tebangan karena lokasi ini berada dekat dengan pemukiman penduduk. Diduga beberapa orang dari masyarakat Desa Ulu Maras masih memanfaatkan pohon bakau untuk membuat alat tangkap dari jenis bubu. Nilai rata-rata tebangan terbesar berikutnya diikuti oleh St.1, St.3 dan St.2 dengan berurutan nilainya sebagai berikut $667 \pm 58$ pohon/ha, $533 \pm 208$ pohon/ha, $133 \pm 231$ pohon/ha dan $33 \pm 58$ pohon/ha (Tabel 2). Untuk melihat perbandingan nilai rata-rata tebangan pohon mangrove pada masingmasing stasiun pengamatan dapat dilihat pada Gambar 5.

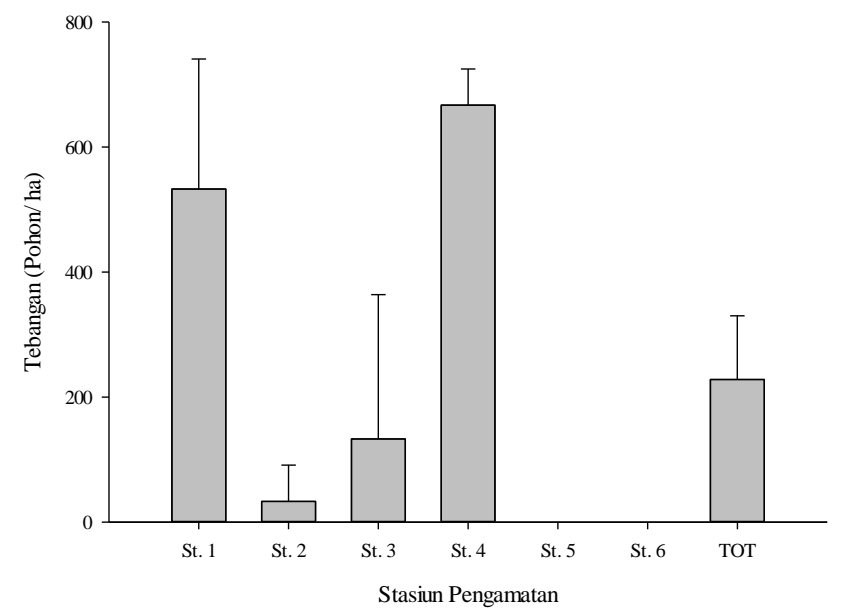

Gambar 5. Perbandingan nilai rata-rata tebangan pohon mangrove pada tiap stasiun pengamatan (St.1-6) dan nilai rata-rata total (TOT) 
Sampah plastik ditemukan pada semua kelompok ukuran (ukuran kecil, sedang dan besar) di stasiun pengamatan yang dekat dengan pemukiman. Sampah plastik untuk semua ukuran ditemukan pada stasiun pengamatan St. 3 dan St.5 dengan nilai jumlah sampah plastik secara berurutan sebagai berikut, ukuran kecil (< $100 \mathrm{~cm} 2$ ) sebesar 200 unit/ha dan 300 unit/ha, ukuran sedang $(100-1600 \mathrm{~cm} 2)$ sebesar 1600 unit/ha dan 1100 unit/ha serta ukuran besar (>1600 $\mathrm{cm} 2$ ) sebesar $500 \mathrm{unit} / \mathrm{ha}$ dan $200 \mathrm{unit} / \mathrm{ha}$. Stasiun pengamatan St.4 hanya ditemukan 300 unit/ha sampah plastik ukuran sedang.

Banyaknya sampah plastik yang ditemukan pada stasiun pengamatan St.3 dan St.5 adalah pengaruh dari limbah rumah tangga yang mana lokasi penelitian berdekatan dengan pemukiman penduduk. Jenis pembungkus makanan merupakan jenis yang paling banyak ditemukan pada lokasi penelitian (Gambar 6).

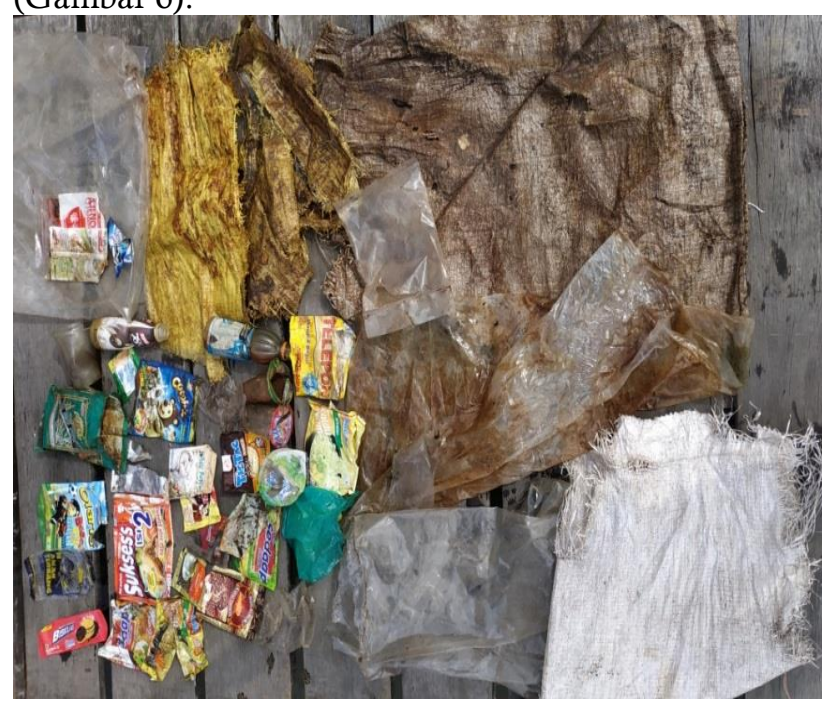

Gambar 6. Sampah plastik yang ditemukan di lokasi penelitian

Berdasarkan hasil analisis fraksi sedimen, pasir berkerikil adalah tipe sedimen di Pesisir Timur Jemaja dengan kandungan kerikil sebesar $(56,86 \pm 14,74 \%)$ pasir $(24,79 \pm 6,44 \%)$ dan lumpur $(18,76 \pm 8,93 \%)$. Fraksi kerikil mendominasi di semua stasiun pengamatan (St.1-6), fraksi sedimen yang tergolong dalam kelompok pasir terdapat pada stasiun pengamatan St.3-6, sedangkan fraksi yang tergolong dalam kelompok lumpur hanya pada stasiun pengamatan St.4 dan St.5.

Nilai $\mathrm{pH}$ rata-rata di lokasi penelitian berkisar antara $6,88 \pm 0,02-8,07 \pm 0,03$. Nilai $\mathrm{pH}$ rata-rata terendah terletak pada stasiun pengamatan St. 4 ( 6,88 $\pm 0,02$ ) yang berlokasi dekat dengan pemukiman sehingga penurunan nilai $\mathrm{pH}$ pada stasiun tersebut diduga berasal dari limbah organik dari pemukiman. Adapun nilai rata-rata $\mathrm{pH}$ tertinggi pada stasiun pengamatan St. $5(8,07 \pm 0,03)$. Berdasarkan baku mutu nilai $\mathrm{pH}$ pada seluruh stasiun pengamatan berada pada kondisi yang baik bagi kehidupan organisme dan mangrove.
Konsentrasi rata-rata oksigen terlarut di Pesisir Timur Jemaja tersebar merata dan hampir seragam tiap stasiun pengamatan pada rentang 2,66 - 3,46 $\mathrm{mg} / \mathrm{L}$. Stasiun pengamatan St.4 dan St.6 memiliki nilai DO rata-rata yang rendah yaitu berkisar antara $2,66-2,93 \mathrm{mg} / \mathrm{L}$. Adapun pada stasiun pengamatan St.1, St.2 St. 3 dan St.5 diketahui bahwa konsentrasi DO rata-rata berkisar antara 3,46 - 3,22 mg/L. Nilai DO tersebut berada dibawah baku mutu berdasarkan Keputusan Menteri Lingkungan Hidup Nomor 51 tahun 2004.

Nilai sanilitas rata-rata di lokasi penelitian berkisar antara 17,43 - 30,13 ppt. Nilai salintas ratarata terendah terletak pada stasiun pengamatan St. 4 dengan nilai salinitas rata-rata sebesar 17,43 ppt. Kondisi tersebut jerjadi dikarenakan lokasi stasiun pengamatan St.4 berada dekat dengan anak sungai sehingga air yang diukur didominasi oleh air payau. Berdasarkan Keputusan Menteri Lingkungan Hidup Nomor 51 Tahun 2004, salinitas rata-rata pada stasiun pengamatan St.1, St.2, St.3, St. 5 dan St. 6 berada pada kisaran yang optimum bagi kehidupan mangrove yaitu sampai dengan 30,13 ppt.

Hasil penelitian menunjukkan bahwa suhu perairan dari seluruh stasiun berkisar antara 28,30 $31,33{ }^{\circ} \mathrm{C}$. Secara umum perbedaan suhu tidak terlalu signifikan antar stasiun pengamatan. Suhu perairan rata-rata tertinggi berada stasiun pengamatan St. 5 dengan nilai $31,33{ }^{\circ} \mathrm{C}$ dan suhu perairan rata-rata terendah berada pada stasiun pengamatan St.6 dengan nilai $28,30{ }^{\circ} \mathrm{C}$.

Nilai kekeruhan di seluruh stasiun pengamatan (St.1-6) memiliki nilai kekeruhan yang tinggi dari baku mutu air laut yaitu berkisar antara 5,10 - 9,27 NTU. Nilai kekeruhan rata-rata tertinggi berada pada stasiun pengamatan St. 3 dengan nilai 9,27 NTU dan nilai ratarata terendah berada pada stasiun pengamatan St. 6 dengan nilai 5,10 NTU. Tingginya nilai rata-rata kekeruhan pada stasiun pengamatan St.3 erat kaitannya dengan lokasi penelitian yang berada dekat dengan pemukiman dan kondisi substrat pasir berlumpur. Sedangkan pada lokasi St. 6 berada dekat dengan perairan terbuka dengan substrat dominan berpasir sehingga nilai kekeruhannya rendah. Berdasarkan kondisi tersebut kekeruhan di semua stasiun pengamatan melebihi baku mutu kekeruhan air laut untuk biota laut yang ditetapkan Keputusan Menteri Lingkungan Hidup Nomor 51 tahun 2004 yaitu kurang dari 5 NTU.

\section{PEMBAHASAN}

Komunitas mangrove di Pesisir Timur Jemaja Kabupaten Kepulauan Anambas tumbuh pada habitat yang beragam. Stasiun pengamatan St.4 yang merupakan kawasan teluk yang terlindungi dan dekat dengan aliran sungai memiliki tipe substrat yang halus (lumpur pasir berkerikil) sedangkan stasiun pengamatan lain didominasi oleh substrat pasir berlumpur. Jumlah jenis mangrove yang ditemukan di Pesisir Timur Jemaja Kabupaten Kepulauan Anambas 
adalah 5 jenis. Empat jenis mangrove mayor yang terdiri dari $R$. apiculata, $R$. mucronata, B. gymnorrhiza dan C.tagal serta satu jenis mangrove minor yaitu $X$. granatum.

Jenis $R$. apiculata mendominasi dari jenis lain yang ditunjukkan dari nilai INP rata-rata tertinggi, yaitu sebesar 123,12\%. Darmadi et al. (2012) berpendapat bahwa R. apiculata pada umumnya dapat tumbuh dengan baik pada tanah berlumpur sampai pasir berlumpur. Kerapatan rata-rata mangrove kelas pohon, pancang dan semai di kawasan ini adalah sebanyak $1611 \pm 297$ (ind/ha), $1544 \pm 934$ (ind/ha) dan $2739 \pm 913$ (ind/ha). Kerapatan vegetasi tingkat semai lebih tinggi dibandingkan kerapatan tingkat pohon dan pancang mengindikasikan bahwa proses regenerasi pada areal mangrove tersebut berjalan dengan baik (Rahmania et al., 2019). Tutupan tajuk rata-rata sebesar 84,03 $\pm 3,11 \%$. Berdasarkan acuan Keputusan Menteri Lingkungan Hidup Nomor 201 tahun 2004, bahwa kondisi mangrove di Pesisir Timur Jemaja Kabupaten Kepulauan Anambas termasuk dalam kondisi sangat padat dan baik.

Kerapatan dan tutupan mangrove di Pesisir Timur Jemaja Kabupaten Kepulauan Anambas lebih tinggi bila dibandingkan dengan kerapatan mangrove di Kawasan Konservasi Perairan Daerah Kabupaten Bintan sebesar 2322 ind/ha dan tutupan sebesar 78,32 $\%$ (Dharmawan et al., 2018). Hasil penelitian ini juga lebih tinggi dibandingkan dari hasil penelitian Nurdiansah et al. (2018) terhadap komunitas mangrove di Wilayah Pesisir Pulau Tidore dan sekitarnya dengan nilai kerapatan dan tutupan sebesar 1.275 ind/ha dan 73,13 (\%). Ini menunjukkan bahwa komunitas mangrove di Pesisir Timur Jemaja Kabupaten Anambas memiliki kepadatan yang lebih tinggi dibandingkan dengan dua kawasan konservasi di atas. Akbar et al. (2017) menyatakan tingginya nilai kerapatan mengindikasikan bahwa tingkat regenerasi mangrove jenis tersebut baik dan dapat bertahan pada kondisi lingkungannya. Di luar kawasan konservasi, kerapatan dan tutupan mangrove Pesisir Timur Jemaja juga lebih tinggi dibandingkan dengan kerapatan dan tutupan mangrove di Kawasan Ujung Piring Kabupaten Jepara dengan nilai kerapatan dan tutupan sebesar 2061 ind/ha dan 65,15\% (Mauludin et al., 2018). Kecamatan Sekotong Lombok Barat dengan kerapatan 2055 ind/ha dan tutupan 66,60 \% (Japa dan Didik, 2018).

Ancaman kerusakan mangrove yang ada di kawasan ini berasal dari limbah anorganik (sampah plastik) dari pemukiman. Desy et al. (2018) menyatakan bahwa sampah plastik dapat menutupi pneumatophore akar mangrove sehingga menggangu sistem pernafasan.

Tiga lokasi penelitian yang dekat dengan pemukiman ditemukan sejumlah sampah plastik berbagai ukuran sedangkan stasiun pengamatan yang jauh dari pemukiman tidak ditemukan sampah plastik (Tabel 2). Jenis sampah plastik yang paling banyak ditemukan adalah jenis kantong plastik dan plastik pembungkus makanan. Thiel et al. (2013) menemukan kantong plastik, peralatan memancing, wadah makanan dan minuman adalah komponen yang paling umum dan lebih dari $80 \%$ dari sampah yang terdampar di pantai. Selain itu pembangunan dan pembukaan akses untuk jalan juga menjadi ancaman terhadap keberadaan mangrove di wilayah ini. Dari hasil pengamatan di lapangan ditemukan beberapa titik mangrove dialihfungsikan menjadi lapangan olah raga dan jalan (Gambar 7).

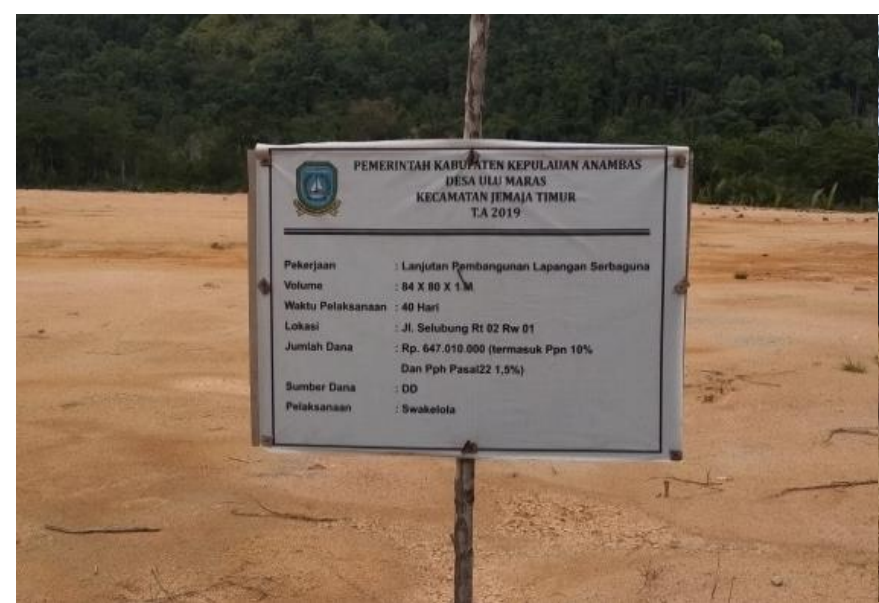

(1)

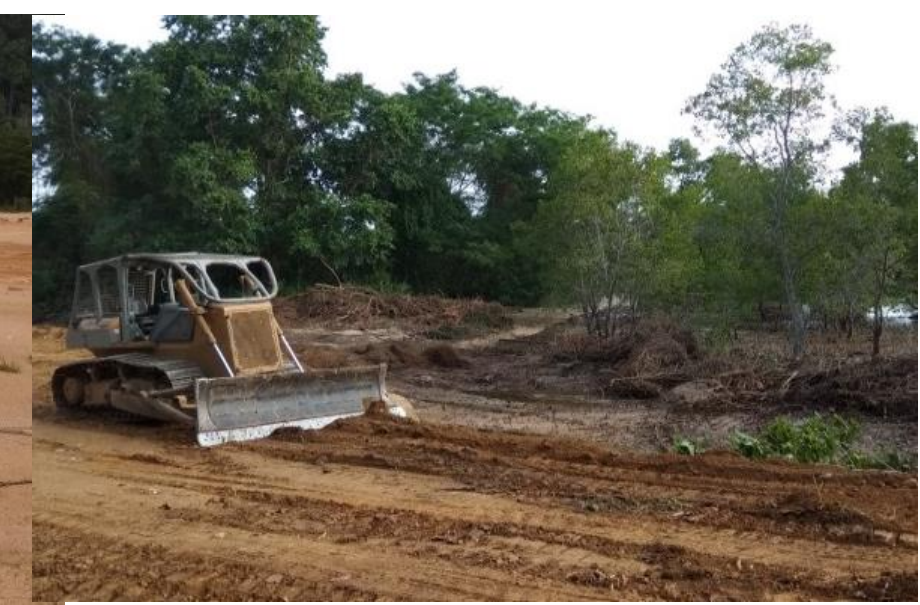

(2)

Gambar 7. Alih fungsi lahan mangrove. (1) pembangunan lapangan serbaguna di Kecamatan Jemaja Timur yang menguruk habitat mangrove; (2) pembukaan akses jalan desa.

Ekosistem mangrove di wilayah Pesisir Timur Jemaja Kabupaten Kepulauan Anambas merupakan salah satu dari tiga ekosistem kunci pesisir yang menjadi target pengelolan konservasi oleh Loka Kawasan Konservasi Perairan Nasional Pekanbaru
(LKKPN Pekanbaru). Pemanfaatan ekosistem mangrove secara lestari di wilayah ini sudah mulai diupayakan seperti pembuatan tracking mangrove untuk aktivitas wisata yang dapat dimanfaatkan oleh warga 
sebagai tempat wisata dan tempat edukasi bagi para siswa yang belajar tentang mangrove (Gambar 8).

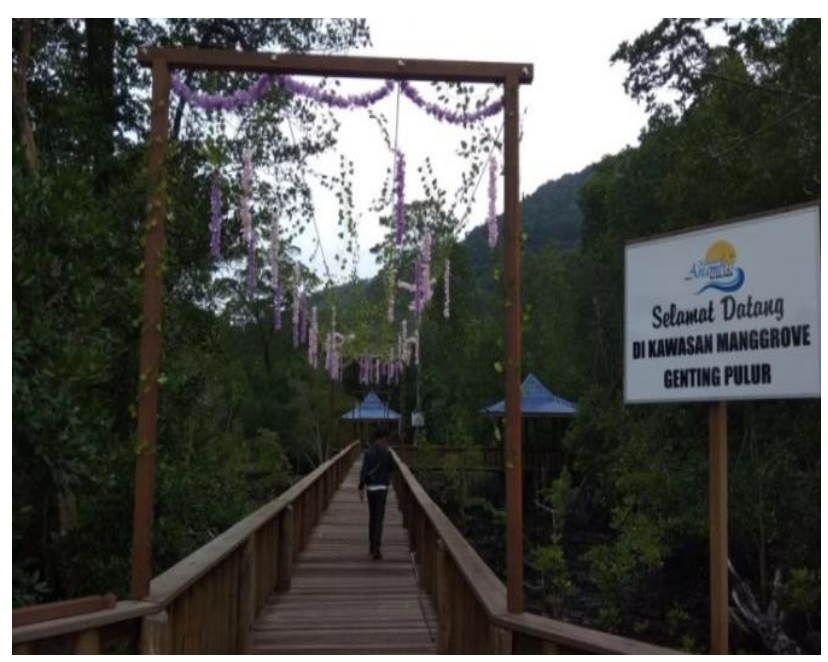

Gambar 8.

Pemanfaatan ekosistem mangrove untuk wisata

Berdasarkan hasil diskusi dengan masyarakat di lokasi penelitian diperoleh informasi bahwa saat ini

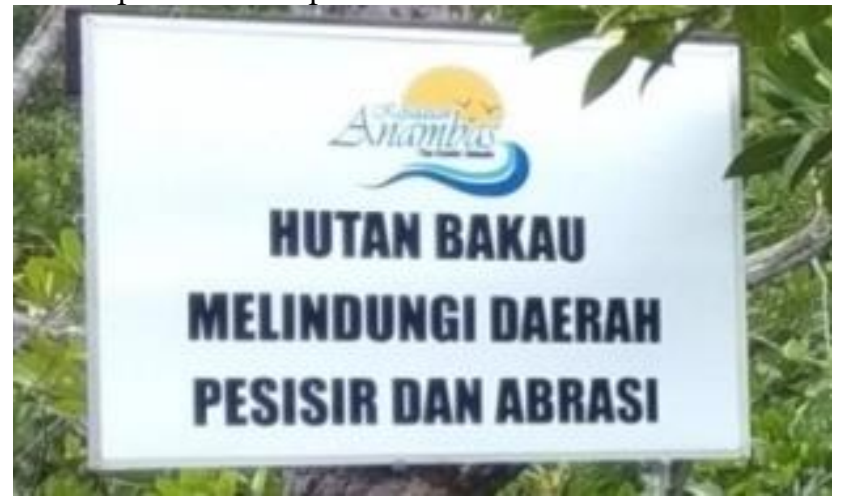

(a) kesadaran masyarakat untuk menjaga dan melestarikan hutan mangrove yang ada diwilayah tersebut sudah cukup tinggi ini dibuktikan dengan sedikitnya jumlah tebangan yang ditemukan di lokasi penelitian dengan rata-rata 2 pohon/100 $\mathrm{m}^{2}$. Kesadaran masyarakat mulai bangkit setelah menyaksikan dampak tsunami di Aceh pada tahun 2004 melalui media televisi. Selain itu pemanfaatan hutan mangrove yang dilakukan oleh masyarakat juga cukup terbatas hanya digunakan untuk membuat kerangka alat tangkap bubu.

Untuk menumbuhkan rasa peduli dan peningkatan penyadartahuan masyarakat akan pentingnya menjaga mangrove, pemerintah dan pengelola kawasan (LKKPN Pekanbaru) terus melakukan berbagai program kegiatan sosialisai dan edukasi baik di tingkat masyarakat maupun bagi pelajar setempat (Gambar 9). Bentuk sosialisasi yang dilakukan berupa pemasangan papan himbauan, tatap muka dengan masyarakat melalui diskusi terarah, aksi bersih pantai, dan edukasi melalui program TWP Goes to School.

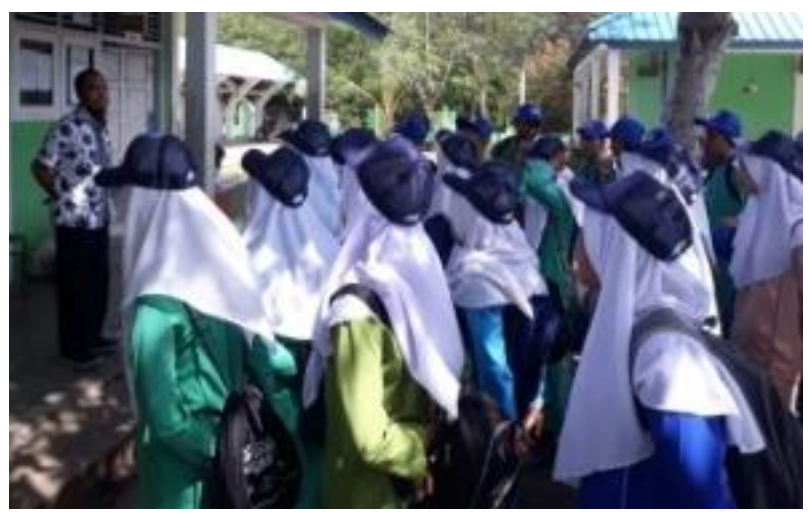

(b)

Gambar 9. Penyadartahuan masyarakat (a) salah satu bentuk papan informasi; (b) sosialisasi dan edukasi tingkat pelajar di Jemaja Timur

Dari kegiatan penyadartahuan tersebut diharapkan masyarakat di berbagai tingkatan mulai dari nelayan, pemuda, pelajar, dan stakeholder lainnya menjadi paham dan menyadari akan pentingnya menjaga dan melestarikan ekosistem mangrove yang ada di wilayahnya sehingga keberadaan ekosistem ini tetap ada dan meningkat untuk menjaga keseimbangan alam dan sebagai penyedia produk perikanan.

\section{SIMPULAN}

Komunitas mangrove di Pesisir Timur Jemaja Kabupaten Kepulauan Anambas tumbuh pada habitat yang beragam. Ditemukan 5 jenis mangrove di lokasi penelitian. Jenis $R$. apiculata merupakan jenis yang mendominasi dibandingka jenis lain dengan nilai INP sebesar $123,12 \%$. Kerapatan rata-rata mangrove kelas pohon dan pancang di kawasan ini adalah $3155 \pm 785$ individu/ha dan tutupan tajuk rata-rata sebesar 84,03 $\pm 3,11 \%$. Berdasarkan acuan Keputusan Menteri
Lingkungan Hidup Nomor 201 tahun 2004, bahwa kondisi mangrove di Pesisir Timur Jemaja Kabupaten Kepulauan Anambas termasuk dalam kondisi sangat padat dan baik. Acaman kerusakan terhadap ekosistem mangrove di kawasan ini berasal dari penebangan, sampah plastik dan alih fungsi lahan.

\section{UCAPAN TERIMA KASIH}

Penulis menyampaikan terima kasih kepada Loka Kawasan Konservasi Perairan Nasional Pekanbaru dan Petugas Wilker Taman Wisata Perairan Kepulauan Anambas yang telah memfasilitasi penulis dalam melakukan penelitian ini. Selanjutnya ucapan terima kasih juga disampaikan kepada seluruh pihak yang membantu dalam kelancaran penelitian ini. 


\section{DAFTAR PUSTAKA}

Akbar, N., I, Marus., I, Haji., S, Abdullah., S, Umalekhoa., F. S, Ibrahim., M, Ahmad., A, Ibrahim., A, Kahar \& I, Tahir. (2017). Struktur Komunitas Hutan Mangrove di Teluk Dodinga Kabupaten Halmahera Barat Provinsi Maluku Utara. Jurnal Enggano. 2(1): 78-89. DOI: 10.31186/jenggano.2.1.78-89

Bengen, D. G. (2004). Pengenalan dan Pengelolaan Ekosistem Mangrove. Pusat Kajian Pesisir dan Lautan (PKSPL). Institut Pertanian Bogor.

Darmadi, M., W, Lewaru., A. M, Khan. (2012). Struktur Komunitas Vegetasi Mangrove Berdasarkan Karakteristik Substrat Di Muara Harmin Desa Cangkring Kecamatan Cantigi Kabupaten Indramayu. Jurnal Perikanan dan Kelautan. 3 (3) : 347- 358.

Desy, R., R, Sugito., T. H. W, Atmajaya. (2018). Sampah Anorganik Sebagai Ancaman Di Kawasan Ekosistem Hutan Manggrove Kuala Langsa. Jurnal Jeumpa 5 (2) : 84-90.

Dharmawan, I. W. E, \& S, Pramudji. (2017). Panduan Monitoring Status Kesehatan Komunitas Mangrove Edisi 2. Pusat Penelitian Oseanografi LIPI. Jakarta.

Dharmawan, I. W. E., B, Prayuda., A. J, Wahyudi. (2018). Potensi Vegetasi Darat dan Mangrove dalam Migitasi Efek Gas Rumah Kaca. In A. J. Wahyudi (Ed.), Menyerap Karbon Layanan Ekosistem Pesisir untuk Mitigasi Perubahan Iklim (pp. 72-95). Yogyakarta: Gadjah Mada University Press.

Dharmawan, I. W. E. \& A. Widyastuti. (2017). Pristine Mangrove Community in Wondama Gulf, West Papua, Indonesia. Marine Research Indonesia 42 (2): 67-76.

DOI:10.14203/mri.v42i2.175.

English, S., C, Wilkinson., V, Baker. (1994). Survey Manual for Tropical Marine Resources. ASEAN Australian Marine Science Project: Living Coastal Resources. Townsville. 368 pp.

Giesen, W., S, Wulffraat., M, Zieren., L, Scholten. (2006). Mangrove Guidebook for Southeat Asia. Bangkok (TH): FAO dan Wetlands International.

Giri, C., E. Ochieng, L. L. Tieszen, Z. Zhu, A. Singh, T. Loveland, J. Masek and N. Duke. (2011). Status and Distribution of Mangrove Forests of the World Using Earth Observation Satellite Data. Global Ecology and Biogeography 20 (1): 154-59. DOI:10.1111/ j.1466-8238. 2010. 00584.x.

Japa, L \& D, Santoso. (2018). Analisis Komunitas Mangrove di Kecamatan Sekotong Lombok Barat NTB. Jurnal Biologi Tropis. 19(1): 25-33. DOI: 10.29303/jbt.v19i1.1001.

Kementerian Lingkungan Hidup. (2004). Keputusan Menteri Negara Lingkungan Hidup Nomor 201 tentang Kriteria Baku dan Pedoman Penentuan Kerusakan Mangrove. Jakarta.
Kementerian Lingkungan Hidup. (2004). Keputusan Menteri Negara Lingkungan Hidup Nomor: 51 tentang Baku Mutu Air Laut. Jakarta.

Mauludin, M. R., R, Azizah., R, Pribadi., Suryono. (2018). Komposisi dan Tutupan Kanopi Mangrove di Kawasan Ujung Piring Kabupaten Jepara. Buletin Oseanografi Marina. 7(1): 29-36. DOI: 10.14710/buloma.v7i1.19039.

Nurdiansyah, D., I. W. E, Dharmawan. (2018). Komunitas Mangrove di Wilayah Pesisir Pulau Tidore dan Sekitarnya. Oseanologi dan Limnologi di Indonesia 3 (1): 1-9 DOI : 10.14203 /oldi.2018.v3i1.63.

Perera., Roshan., M. D, Amarasinghe. (2019). Carbon Sequestration Capacity of Mangrove Soils in Micro Tidal Estuaries and Lagoons: A Case Study From Sri Lanka. Geoderma Journal. 347: 80-89. DOI: 10.1016/j.geoderma.2019.03.041.

Pramono, J. (2018). Rencana Aksi Rehabilitasi Hutan Mangrove di Indonesia : Sarasehan Konservasi Ekosistem Mangrove sebagai Sistem Penyangga Kehidupan. Fakultas Kehutanan IPB. Bogor.

Rahmania, R., Sunarni., M. R, Maturbongs., T. Arifin. (2019). Zonasi dan Struktur Komunitas Mangrove di Pesisir Kabupaten Merauke. Jurnal Kelautan Nasional. 14 (3) : 165-178. DOI:10.15578/jkn.v14i3.7961.

Thiel, M., I. A, Hinojosa., L, Miranda., J. F, Pantoja., M. M, Rivadeneira., N, Vásquez. (2013). Anthropogenic marine debris in the coastal environment: A multi-year comparison between coastal waters and local shores. Marine Pollution Bulletin. 71: 307-316. 